\title{
Os poderes do mal e as máscaras do diabo
}

\author{
The powers of evil and the devil masks
}

\begin{abstract}
Valmor da Silva
Doutor em Ciências da Religião, professor na Teologia e no Programa de Pós-Graduação em Ciências da Religião da Pontifícia Universidade Católica de Goiás (PUC Goiás), Goiânia, G0 - Brasil, e-mail: lesil@terra.com.br
\end{abstract}

\section{Resumo}

Este trabalho apresenta um panorama sobre o mal nas diversas ciências e, principalmente, na Bíblia e no cristianismo, buscando dissociá-lo das máscaras do diabo. Nas ciências, expõe a noção de mal na antropologia, na literatura sagrada, na sociologia, na psicologia, na filosofia e nas religiões. Segue com a demonização do desconhecido, em que apresenta culturas que não apelam para a figura do demônio e para outras em que suas divindades são vistas como demônios. Perfaz, enfim, a história do mal na Bíblia, com a ideia de que sua representação passou a ser feita apenas após o exílio. Destaca momentos em que o mal não possui personificação, seja na Bíblia seja no cristianismo.

Palavras-chave: Diabo. Divindades. Mal. Poder.

\section{Abstract}

An overview over evil in the various sciences, and especially in the Bible and Christianity, seeking to disassociate it from the masks of the devil. In science, debunks the notion 
of evil in anthropology, sacred literature, sociology, psychology, philosophy and religion. Follows with the demonization of the unknown, which shows that cultures do not appeal to the figure of the devil and others in which deities are seen as devils. Make up short, the history of evil in the Bible, with the idea that their representation has been made only after the exile. Highlights moments in which evil has no personification, is in the Bible, Christianity.

Keywords: Devil. Gods. Evil. Power.

\section{Introdução}

O mistério do mal é um problema insolúvel para a humanidade. Ao longo da história, inúmeras explicações foram apresentadas, nenhuma satisfatória. A solução mais comum identifica o mal com o diabo, como a face oposta do bem, identificada com Deus. Russel (1991), por exemplo, traça uma história dessa evolução, que chegou a identificar o diabo como a personificação do mal. Trata-se do resultado simples de um dualismo que distingue dois princípios, um para o bem e outro para o mal. O dualismo, porém, simplifica o problema. Cada época histórica e cada cultura procuraram responder a seu modo ao mistério do mal. Se tirássemos as máscaras históricas e culturais, o que restaria?

Numa visão panorâmica, o presente texto faz eco ao ditado popular, segundo o qual "o diabo não é tão feio como pintam”. Em outras palavras, trata-se da tentativa de demonstrar que nem sempre foi necessário, ao longo da história, apelar para um ser externo, mitológico, que explicasse o mal inerente à humanidade. As várias representações culturais do mal, adaptadas a cada época ou sociedade, são, na verdade, projeções de seus medos e de suas desgraças. Desse modo, o mal se revestiu de diversas representações, mascarado como diabo, demônio, satanás e tantos outros personagens.

A atribuição do mal ao demônio se desenvolveu principalmente no cristianismo. Em diversas épocas da história, o diabo rivalizou com Deus em sinais, milagres e prodígios. Hoje mesmo, por certo, satanás tem muito mais propaganda do que merece. Será legítimo esse processo? 


\section{Olhares das ciências sobre o mal}

\section{0 mal como representação cultural}

Do ponto de vista antropológico, o mal é representado de acordo com o imaginário de cada cultura. Essa representação é simbólica, mas se apresenta como real, porque interpreta a realidade. Tal interpretação é feita por meio de símbolos, ritos, crenças, discursos e representações alegóricas figurativas. A isso se chama imaginário. Assim sendo, cada grupo humano cria o seu imaginário, isto é, "um sistema de idéias e imagens de representação coletiva” (PESAVENTO, 1995, p. 9).

Com relação ao mal, o imaginário coletivo tem sido particularmente criativo em inventar representações diferenciadas. Empenha-se em explicar o desconhecido, o estranho e o contrário. Há respostas como destino, má sorte, castigo, desgraça, provação. Destacam-se, porém, as explicações que atribuem o mal a seres celestes, opostos a Deus, como demônios ou espíritos do mal (SCHIAVO, 2000, p. 66).

\section{0 mal como símbolo literário}

A literatura sagrada exprime a experiência do mal em narrativas literárias, representadas simbolicamente em forma de mitos. Praticamente todos os livros sagrados, de todas as religiões, procuram dar explicações para o mal, sua origem, seu significado e sua função na vida humana. O imaginário coletivo, dessa forma, é fixado em relatos literários, que refletem, de maneira simbólica, as concepções diversas de cada cultura.

A experiência do mal é tão complexa que só pode ser explicada de maneira simbólica. O ser humano experimenta o mal como falta e o exprime, simbolicamente, em vários níveis. O primeiro nível, da impureza, é simbolizado pela mancha, como algo que atinge a pessoa de fora. $\mathrm{O}$ segundo nível, do pecado, é simbolizado pelo extravio ou exílio, como expressão do mal vivido na relação com alguém. O terceiro nível, da culpa, é simbolizado como peso ou carga, e exprime a vivência do mal interno à própria pessoa (CROATTO, 2001, p. 118-121). 


\section{0 mal como desordem social}

Segundo a sociologia da religião, o mal é aquilo que foge aos padrões estabelecidos pelo grupo social. A ordem pública é atribuída a um deus, tanto mais forte quanto mais ético. O correspondente comportamento ético dos fiéis é assegurado pelo tabu, que determina normas e proibições. Quebrar o tabu ou contradizer o comportamento ético da divindade é incorrer num desvio conhecido como pecado (WEBER, 1999, p. 295-303).

O mal pode ser algo relacional enquanto se insere nas lutas pelo poder. Esse eixo de poder é normalmente a tentativa de controlar os saberes (FOUCAULT, 1979, p. 113-128).

No cotidiano das relações sociais, o mal adquire diferentes nomes, de acordo com as formas como se materializa. O mal está, normalmente, na teoria do outro, que é o estranho ou o diferente. Pode ser o migrante com relação ao nativo, ou o caos com relação à ordem estabelecida (BAUMAN, 1999, p. 9-61). Pode se caracterizar também como crime e desvio diante dos padrões estabelecidos pela sociedade (GIDDENS, 2005, p. 172-182).

\section{0 mal como sombra}

$\mathrm{Na}$ ótica da psicologia profunda, especialmente a psicologia analítica de Carl Gustav Jung, o problema do mal deve ser relacionado com o aspecto sombra da personalidade humana. "O termo 'sombra', como conceito psicológico, refere-se ao lado obscuro, ameaçador e indesejado da nossa personalidade" (SANFORD, 1988, p. 64). O lado sombra é uma espécie de segunda personalidade da pessoa humana e representa ideais reprimidos, sentimentos não vivenciados, senso de humor, fantasias diversas. A sombra é um arquétipo, ou seja, faz parte de toda personalidade. Pode se configurar também como sombra coletiva, quando projetada sobre grupos, como protestantes sobre católicos ou vice-versa. O conhecimento da sombra pode ser de grande valia na compreensão do problema do mal, pois o percebe como projeção das forças-mestras da psique humana. 


\section{0 mal como não ser}

Para a filosofia, "a concepção metafísica do Mal consiste em considerá-lo como o não-ser diante do ser, que é o bem, ou em considerá-lo como uma dualidade do ser, como uma dissensão ou um conflito interno do próprio ser" (ABBAGNANO, 1999, p. 638). Visto como não ser, o mal é ausência, deficiência, nulidade ou privação do bem. Na base desse raciocínio está o fato de que tudo o que existe é bom. Mal, em consequência, é o que não existe, o não ser. Essa doutrina, já sugerida por Aristóteles, foi formulada explicitamente pelo neoplatonismo e percorre praticamente toda a história da filosofia.

A filosofia cristã aderiu à ideia tradicional do mal como não ser, e cunhou a ideia como privação do bem, popularizada até em sua forma latina como privatio boni. O dicionário de Abbagnano (1999, p. 638-639) elenca os propositores dessa tese, a partir das citações de Agostinho, que afirma: "nenhuma natureza é Mal, e esse nome indica apenas a privação do bem" (De civ. Dei, XI, 22). Portanto, "todas as coisas são boas, e o Mal não é substância porque se fosse substância seria bem" (Conf., VII, 12).

Pierre Gisel, no prefácio à obra sobre o mal, de Paul Ricoeur (1988, p. 17), retoma com ênfase essa afirmação: "primeiro ponto a considerar: o mal não é uma coisa, um elemento do mundo, uma substância ou uma natureza. Todos os Padres da Igreja o afirmaram. Contra toda a gnose (todo o pensar em forma inicial de saber)".

\section{0 mal como oposto ao bem}

A teoria que mais se popularizou e domina praticamente todo o senso comum é a do dualismo que contrapõe o mal ao bem. Do ponto de vista filosófico, essa "concepção metafísica do mal considera-o como um conflito interno do ser, como a luta entre dois princípios" (ABBAGNANO, 1999, p. 639). Espelha-se no modelo da religião persa, do zoroastrismo, segundo o qual há uma divindade do bem e uma antidivindade do mal. O culto de Mitra retoma o dualismo entre bem e mal, luz e trevas. Ideias dualistas ressurgem igualmente em seitas gnósticas do início do cristianismo. 
E retoma traços dualistas o maniqueísmo, contra o qual argumentou Agostinho. Embora o dualismo não seja aceito como teoria filosófica nem como doutrina teológica, ele ganha terreno nas ideias divulgativas que opõem bem e mal, Deus e diabo, eixo do bem e eixo do mal, mocinho e bandido, e tantos outros binômios inumeráveis.

Mas há o dualismo não absoluto, encontrado em muitas religiões antigas, e estudado como "dualismo primitivo" (CROATTO, 2001, p. 169175). Esse dualismo não considera dois princípios geradores, um para o bem e outro para o mal. Bem e mal podem ter origem independente, a partir de um mesmo princípio criador. Não são opostos, mas complementares. Estão na mesma dimensão de dia e noite, céu e terra, masculino e feminino. Religiões e filosofias orientais traduzem isso na ideia de yin e yang, como dois opostos que se completam. Em culturas africanas ou aborígenes da América Setentrional e da Patagônia se manifesta na figura do trickster ou "enganador", geralmente um animal, coiote, lobo ou raposa. $\mathrm{Na}$ religião egípcia, como em outras, é a figura da serpente que representa a ideia do mal.

\section{A demonização do desconhecido}

\section{0 mal como mal ausente}

Determinadas culturas, principalmente indígenas, não possuem noção clara de mal e, portanto, não têm representações para essa realidade. A própria noção de bem é vaga e diluída.

Os elgonys constituem uma tribo africana de mentalidade otimista descrita por Jung em sua autobiografia e apresentada por Sanford (1988, p. 24-25). Acreditam num criador que só fez o bem. "Ele estava além do bem e do mal. Ele era m'zuri, quer dizer, bonito. E tudo que ele criara era m'zuri". Ao serem interrogados sobre os animais ferozes que matam os rebanhos, respondem a Jung: “o leão é bom e bonito". E ao serem questionados mais além, sobre as doenças que os atacam, prosseguem: "A gente fica deitado no sol e é bom". Jung se impressiona muito, mas observa que, após o pôr do sol, o otimismo cede lugar ao medo dos fantasmas e 
as práticas mágicas evocam a busca de proteção. Ao amanhecer, naturalmente, retorna o otimismo de sempre.

Os avás-canoeiros, indígenas de Goiás, não possuem o conceito do mal como força eterna e absoluta, conforme relata Mário Arruda, antropólogo e pesquisador da Universidade Católica de Goiás (SCHIAVO; SILVA, 2002, p. 51). O dilema dos brancos, vivendo entre um deus bondoso e um deus agressivo, é motivo de riso para eles. Consideram a força cósmica sempre positiva. Se admitem o mal, este não depende da natureza, mas da experiência que o ser humano faz com ela. A cobra lá está, sem causar mal, a não ser que alguém vá provocá-la. A chuva é boa, como é bom o sol e toda a natureza. Cabe à pessoa integrar-se nesse universo bom. A partir dessa compreensão integradora, os avás-canoeiros não têm medo de nada.

\section{A demonização do outro}

É muito comum, ao longo de toda a história, o processo de atribuir traços demoníacos à cultura que representa o outro, o diferente ou o estranho.

Os indígenas do planalto andino, na atual região do Peru e da Bolívia, entronizavam, à entrada das minas de ouro e prata, uma figura para guardar o ambiente subterrâneo. Era um ser protetor, guardião da mina, invocado para mostrar os caminhos do metal precioso. A essa figura os índios devotavam respeito, pois podia mostrar, como também podia esconder, para eles, o ouro e a prata. Mas os colonizadores, ao chegarem, demonizaram essa criatura e a transformaram num ser maléfico e perigoso. O mesmo processo de demonização aconteceu com os demais deuses indígenas. Hoje em dia, ainda se pode ver, à entrada das minas, a figura denominada el tío, com traços folclóricos e inofensivos.

Na mesma região do antigo Peru, os incas, que apelam para sacerdotes, bruxos e curandeiros na cura de suas doenças, donos de admirável cultura, desconhecem o mal como causa das desgraças. O próprio autor Di Nola (2004, p. 33), que vê o diabo em todas as culturas, conclui, acerca dos incas: "faltam menções precisas, na mitologia, de figuras demoníacas". 
Um dos casos mais significativos de demonização é a do Exu, o orixá dos iorubas, processo bem descrito por Prandi (2001, p. 46-65). Exu é, em suas origens, um orixá, isto é, uma verdadeira divindade. Mais que isso, ele é o transportador, encarregado de levar as oferendas dos seres humanos até o mundo dos deuses. É também o mensageiro, encarregado de trazer as mensagens dos deuses aos seres humanos. Sua função, portanto, é a mais importante em toda a criação. "Exu é o portador das orientações e ordens, é o porta-voz dos deuses e entre os deuses". Mas ele é também o transformador, pela sua capacidade de promover mudanças, inovar, transformar. Por isso, é também temido. É ele o patrono da cópula, promotor do sexo e da prole, aspectos fundamentais para as culturas antigas. Essas características do Exu serviram para o catolicismo transformá-lo de divindade em figura demoníaca, uma "divindade caluniada", no dizer de Roger Bastide. A noção de bem e mal, opondo pecado e virtude, que "não existia na África”, atribuiu ao Exu tabus e pecados, e o adaptou ao inferno católico.

\section{Na Bíblia}

A maneira como o mal aparece na Bíblia Hebraica é exemplar para a compreensão desse conceito. A partir de uma vaga noção de mal, chegou-se à concepção de demônios ameaçadores. Mesmo assim, a presença diabólica nos textos bíblicos está longe da imagem que se pinta nas interpretações corriqueiras.

\section{Só Yhwh é Deus}

Nos inícios do povo judeu, conforme a Bíblia Hebraica, não existe noção clara de mal nem representações de demônios. A razão para isso parece clara. Yhwh é Deus único (Dt 6,4). Fora dele não há Deus. Essa afirmação de fé vai se firmando gradativamente, em vista de uma noção de monoteísmo absoluto (SCHIAVO; SILVA, 2002, p. 55).

Nessa concepção, tudo o que acontece vem de Deus. Mesmo que o ser humano seja submetido a dura prova, tal ocorrência é vista como um 
bem. Ao perder tudo o que possuía, Jó bendiz a Deus. "O Senhor o deu, o Senhor o tirou, bendito seja o nome do Senhor" (Jó 1,21).

\section{Quem manda o mal}

A questão sobre quem manda o mal possui resposta simples. Se Yhwh é o Deus único e não admite concorrente, ele é o autor de tudo o que acontece, portanto é autor também do mal. Mas, longe do povo, a ideia de que Deus possa ser causa dos males. Trata-se de um "dualismo mitigado", na expressão de Croatto (2001, p. 172). Segundo Kilpp (2002, p. 25), o monoteísmo de Israel "é responsável pela falta de um dualismo radical entre o bem e o mal e também pela inexistência de uma demonologia no Antigo Testamento". Pinzetta (2002, p. 37) vai mais longe ao afirmar que "não existe um princípio original do mal na literatura judaica".

Inúmeros são os exemplos em que Yhwh aparece como autor do mal, no Primeiro Testamento (SANFORD, 1988, p. 39). "Se acontece alguma desgraça na cidade, não foi Yhwh quem agiu?” (Am 3,6). "Eu sou Yhwh e não há nenhum outro [...]. Eu formo a luz e crio as trevas, asseguro o bem-estar e crio a desgraça: sim, eu, Yhwh, faço tudo isto" (Is 45,5-7). "Sabe que fui eu quem criou o ferreiro que sopra as brasas no fogo e tira delas o instrumento para seu uso; também fui eu quem criou o exterminador, com a função de criar ruínas" (Is 54,16). A Bíblia nos informa que "um mau espírito da parte de Deus assaltou Saul" $(1 S m$ 18,10) quando o rei tem acessos de depressão e violência. Na história de Balaão, Deus aparece como um satã ou um inimigo, ao afirmar que "a sua partida excitou a ira de Yhwh e o Anjo de Yhwh se colocou na estrada, para barrar-lhe a passagem" (Nm 22,22). Isso mostra, segundo Sanford (1988, p. 43-44), o lado obscuro, destrutivo e demoníaco do si mesmo de Deus.

\section{Satanás como adversário}

O termo "satanás", em sua origem, designa um ser humano que tem a função de adversário. Da mesma forma como um time é adversário 
do outro, satanás tem essa função de opositor, sem necessariamente caracterizar uma ação negativa. Para os generais filisteus, Davi é considerado um satanás, isto é, um guerreiro adversário. "Que não aconteça que no combate seja um satanás para nós” (1Sm 29,4). Noutra passagem, Abisaí é reprovado por Davi como satanás, por querer matar Semei ( 2 Sm 16,10; 19,23). Igualmente Razon é satanás ou adversário de Salomão e de Israel (1Rs 11,23). No Sl 109,6 se lê: "designa um ímpio contra ele, que um acusador (satanás) se poste à sua direita”. Satanás era, portanto, em sua origem, apenas um apelido para seres humanos (SCHIAVO; SILVA, 2002, p. 56-57).

\section{Satã como íntimo de Deus}

No livro de Jó, curiosamente, Satã aparece entre os filhos de Deus (Jó 1,6). Ele vive na intimidade da corte divina e conversa familiarmente com Deus. Passeia entre os seres humanos e tem livre acesso ao céu e a terra. É claramente um ser distinto de Deus, mas não possui ainda a conotação negativa que assumirá mais tarde (SANFORD, 1988, p. 38-39).

No primeiro Livro de Crônicas, o recenseamento feito pelo rei Davi é atribuído a um personagem misterioso, inimigo de Deus. "Satã levantou-se contra Israel e induziu Davi a fazer o recenseamento de Israel” (1Cr 21,1). $\mathrm{O}$ ato do recenseamento, considerado pecaminoso, trouxe drásticas consequências para o povo. Para explicar essas consequências desastrosas, recorrese a satanás. Vale lembrar que na passagem paralela, de data anterior, não havia satanás na cena, mas a desgraça fora atribuída à "ira de Yhwh" (2 Sm 24,1).

Satanás vai se transformando de agente e mensageiro de Deus em seu adversário, como ilustra outra passagem onde ele é o acusador celeste (Zc 3,1-2). O sumo sacerdote Josué está entre Satã que o acusa e o anjo do Senhor que repreende Satã (SCHIAVO; SILVA, 2002, p. 57-58).

\section{Demônios como divindades estranhas}

A palavra demônio, na Bíblia, possui vários significados, o que torna difícil identificá-la com um ser específico. Já no âmbito da filosofia antiga, 
demônios eram divindades às quais se dirigia o sacrifício do culto, "intermediários entre os homens e a divindade perfeita”. A eles também se imputava tudo o que destoasse do culto, servindo como "descarga para a divindade" (LIMBECK, 1975, p. 286). A palavra demônio equivale também a gênio, responsável pela inspiração artística.

Aos deuses pagãos, a tradução grega dos Setenta, bem como o apóstolo Paulo, chamam de demônios. Eles não representam o mundo diabólico, mas são "destinatários de um culto errado" (LIMBECK, 1975, p. 286). Em Dt 32,17 se lê: "sacrificaram a demônios, falsos deuses, a deuses que não haviam conhecido". E no S1 96,5, onde se afirma: "os demônios dos povos são todos vazios", nossas Bíblias traduzem: "os deuses dos povos são todos vazios". O mesmo costume de nomear os deuses dos outros como demônios se encontra em Sl 106,37; Br 4,7 e outras passagens. No Novo Testamento, Paulo apóstolo, no esforço em distinguir a ceia cristã dos sacrifícios não cristãos, chama os ritos pagãos de idolatria e de imolação aos demônios que, nesse caso, representam divindades não cristãs (1Cor 10,20-22).

\section{Como satanás entrou na Bíblia}

Foi no contexto do pós-exílio, sob a dominação persa, e depois helênica, que se passou a relacionar o mal com a figura de satanás. Até então não se concebia um ser mau que pudesse ser o causador do mal. "Pois até a época do exílio babilônico se considerara, em Israel, o coração do homem e até mesmo o próprio Deus como a origem do mal (cf. Gn 6,5.13; 8,21; 1Rs 11,3-8; 12,28; S1 51,12; Dt 29,3; 1Sm 26,19; 1Rs 12,15; Is 45,7)" (LIMBECK, 1975, p. 287).

O contexto político da dominação persa explica, em parte, a infiltração das explicações demoníacas em Israel. A partir de seu palácio real, por meio de um espião, o rei mantinha o controle sobre todo o império. Essa realidade pode ter influenciado a concepção de palácio celeste em Jó e em Zacarias, onde satanás ocuparia o lugar do espião cognominado "olhos do rei" (LIMBECK, 1975, p. 288).

Mas há uma forte razão teológica no encontro entre as concepções míticas do Antigo Israel com a forte demonologia babilônica. Naquele 
contexto crescera a concepção de seres maus, concorrentes dos deuses, causadores de desgraças sobre a humanidade. O contexto de medo e insegurança do povo judeu, sob ameaça de dominação militar e de infertilidade de campos e rebanhos, foi campo fácil para as representações demoníacas.

As concepções apocalípticas, em torno aos inícios da era cristã, contribuíram decisivamente para a associação do mal com as representações diabólicas, como apresenta Russel (1991, p. 173-223).

\section{0 mal no Novo Testamento}

No Novo Testamento, como evidenciam inúmeros textos, o demônio está solto e passa a explicar muitos males, tais como doenças, desastres, fracassos, pecados e opressões. O contexto político e social favorecia a sensação de impotência diante da forte dominação romana e dos confusos reinados herodianos. Isso sem contar a situação interna das igrejas, com seus conflitos e sofrimentos iniciais.

Mas nem sempre a explicação satânica é necessária para os males que assolam as pessoas. Jesus tem familiaridade com todos os tipos de demônios e os domina soberanamente. Com seus milagres e exorcismos, cura doenças e expulsa demônios. O reino de Deus quebra o reino de satanás.

A paixão de Jesus, se interpretada como provocação de satanás em Lucas e João, não o é em Mateus e em Marcos, que consideram a entrega de Jesus e a dispersão dos discípulos como ação do próprio Deus. Se, por outro lado, o Apocalipse considera o Estado como a corporização de satanás, por outro a primeira carta de Pedro tem olhos positivos para com o Império Romano e até acredita na sua mudança (LIMBECK, 1975, p. 292293). Isso nos leva a concluir que não há, ao longo do Novo Testamento, uma visão uniforme sobre a presença e função dos diabos. Essa conclusão pode ser verificada em inúmeras obras que estudam a presença do diabo na Bíblia Cristã, tais como Russel (1991, p. 225-254) e Pagels (1996). 


\section{No cristianismo}

A presença do mal no mundo, de tão difícil explicação, não teve resposta definitiva na Bíblia Hebraica. Na literatura apócrifa e no Novo Testamento, apesar das propostas alternativas, começou a ganhar forma a associação entre o mal e o demoníaco. Nos inícios do cristianismo, a questão ganhou argumentos acalorados por causa da proposta dualista do gnosticismo, que argumentava pela existência de um ser bom e outro ser mau. Daí o combate claro dessa ideia, como afirma Pierre Gisel, no prefácio a Ricoeur (1988, p. 17): “o mal não é uma coisa, um elemento do mundo, uma substância ou uma natureza. Todos os Padres da Igreja o afirmaram. Contra toda a gnose”. Dirá principalmente Agostinho, que o mal não é uma substância, ou seja, ele não existe ontologicamente (RICOEUR, 1988, p. 32).

A Igreja vive o seu impulso inicial, cheia de otimismo, e tem clareza de sua vitória sobre o reino de satanás. Orígenes "estava persuadido de que o poder do Diabo e suas cortes estava em declínio" (NOGUEIRA, 2002, p. 32). Logo, com a oficialização da Igreja pelo Estado, e a consequente redução da resistência pagã, entendeu-se que as forças infernais estavam definitivamente derrotadas.

Essa ideia perdurou ao longo de muitos séculos no cristianismo. Como afirma Muchembled (2001), "Satã entra em cena" no século XII. Mil anos antes estivera apagado no cristianismo. Mas vai ganhar importância, até triunfar, no final da Idade Média.

É paradoxal, no cristianismo, esse "triunfo de Satã", como apresenta Nogueira (2002). O medo levou à obsessão mórbida pelo diabo, a ponto de dar mais valor a ele do que a Deus. A Europa toda, na Idade Média, vivia dominada pelas ameaças demoníacas. O Islamismo não fugiria a esse terror, tendo criado também um complexo sistema explicativo do mal, com terríveis satanases e infernos. O mesmo terror mórbido ameaça os dias atuais, com uma forte revanche do satanismo. Será possível recuperar a convicção positiva de que o mal não é tão terrível como parece? 


\section{Referências}

ABBAGNANO, N. Dicionário de filosofia. São Paulo: Martins Fontes, 1999.

BAUMAN, S. Modernidade e ambivalência. Rio de Janeiro: Zahar, 1999.

CROATTO, J. S. As linguagens da experiência religiosa: uma introdução à fenomenologia da religião. São Paulo: Paulinas, 2001.

DI NOLA, A. M. Il Diavolo: le forme, la storia, le vicende di Satana e la sua universale e malefica presenza presso tutti i popoli dall'antichità ai nostri giorni. Roma: Newton \& Compton, 2004.

FOUCAULT, M. Microfísica do poder. Rio de Janeiro: Graal, 1979.

GIDDENS, A. Sociologia. 4. ed. Porto Alegre: Artmed, 2005.

KILPP, N. Os poderes demoníacos no Antigo Testamento. Revista Estudos Bíblicos, Petrópolis, n. 74, p. 23-36, 2002.

LIMBECK, M. As raízes da concepção bíblica acerca do diabo e dos demônios. Revista Concilium, Petrópolis, v. 103, p. 282-294, 1975.

MUCHEMBLED, R. Uma história do diabo: séculos XII-XX. Rio de Janeiro: Bom Texto, 2001.

NOGUEIRA, C. R. F. O diabo no imaginário cristão. Bauru: EDUSC, 2002.

PAGELS, E. As origens de Satanás: um estudo sobre o poder que as forças irracionais exercem na sociedade moderna. Rio de Janeiro: Ediouro, 1996.

PESAVENTO, S. J. Em busca de uma outra história: imaginando o imaginário. Revista Brasileira de História, São Paulo, v. 15, n. 29, p. 9-27, 1995.

PINZETTA, I. O mal e suas determinações na história. Revista Estudos Bíblicos, Petrópolis, n. 74, p. 37-41, 2002.

PRANDI, R. Exu, de mensageiro a diabo: sincretismo Católico e demonização do orixá Exu. Revista USP, São Paulo, n. 50, p. 46-65, 2001.

RICOEUR, P. 0 mal, um desafio à filosofia e à teologia. Campinas: Papirus, 1988. 
RUSSEL, J. 0 diabo: as percepções do mal da antiguidade ao cristianismo primitivo. Rio de Janeiro: Campus, 1991.

SANFORD, J. A. Mal: o lado sombrio da realidade. São Paulo: Paulus, 1988.

SCHIAVO, L. O mal e suas representações simbólicas. Revista Estudos da Religão, São Bernardo do Campo, n. 19, p. 65-83, 2000.

SCHIAVO, L.; SILVA, V. da. Jesus, milagreiro e exorcista. São Paulo: Paulinas, 2002.

WEBER, M. Economia e sociedade: fundamentos da sociologia compreensiva. Brasília: Editora da UnB, 1999. v. 1.

Recebido: 11/07/2010

Received: 07/11/2010

Aprovado: 15/09/2010

Approved: 09/15/2010 